\title{
Ineffable space: Le Corbusier's colour schemes for the Monastery Sainte Marie de la Tourette
}

\author{
B. Klinkhammer \\ College of Architecture and Design, The University of Tennessee, \\ Knoxville, USA
}

\begin{abstract}
This paper investigates the colour - and form - gestalt of the Monastery Sainte Marie de la Tourette (1957), linking Le Corbusier's (Charles-Edouard Jeanneret) polychromie architecturale to his concepts of visual acoustics and ineffable space; both essential aspects of his post-war architecture. The richness of the painted surfaces and the glowing colour, created through reflections of natural light onto its boldly painted walls and sculpted objects (such as demonstrated in the sacristy and the crypt of the church), stand in stark contrast to the crude, "bare" concrete that creates a sense of pureness, akin to his early whitewash ideas seen in his Law of Ripolin. This use of industrial, raw products, such as concrete and cement, paired with a sublime but controlled play of colour and natural light, too, mediates between the profane and the sacred to create a space of poetic lyricism and spiritual asceticism.

Keywords: Le Corbusier, polychromy, polychromie architecturale, colour, modern architecture, Monastery Sainte Marie de la Tourette, sacred architecture, post-war architecture, architecture history and theory.
\end{abstract}

\section{Introduction}

Le Corbusier's architectural work, beginning in the early 1920s, reflects his profound research and interest in colour as one of the "fundamental elements in the architectural perception" [2], his essays and writings about colour stress its significance. Transforming his purist concept of polychromie architectural, "Colour completely depends on the material form" [3], colour began to emerge in his buildings, after World War II, as an autonomous design feature in the interplay of architectural elements. While his purist buildings share a 
sophisticated colour palette of muted tones based on the constructive qualities of each hue, his post-war buildings share a colour palette of vibrant, often primary or pure hues employed to evoke strong emotional responses. The Polychromie architecturale for the Monastery Sainte Marie de la Tourette stands in stark contrast to the surrounding concrete surfaces and creates a space of poetic lyricism built upon the spatial and emotional powers of colour.

It is important to consider the architectural polychromy of La Tourette in the context of Le Corbusier's central theories and projects of the post-war period, the demand for a synthesis of the arts and his concept of ineffable space [4]. Ineffable space describes transformation of space as a transcendental event that lies beyond the physical reality of the space. Moreover, the perfect interplay of all the spatial elements creates an aura evoking an invisible humming and vibration of the space caused by visual acoustics, similar to a musical instrument. Visual acoustics, which sometimes also appeared as plastic acoustics in his writings, is used as a trope for a spatial phenomenon describing the interactive play of acoustical waves, light waves, spatial effect and emotional energy. In this framework, the building serves as a sounding board for the surrounding landscape or "visual echo" [5], and also a work of art, radiating visually into the environment.

"The release of aesthetic emotion is a spatial function", wrote Le Corbusier in Espace indicible. This aesthetic emotion is based on a sensed vibration between the "action of the work (architecture, statue or painting) on its surroundings", and the "reaction of the setting" with its walls, dimensions, and its relationship to the landscape. He compared this vibration between object and surroundings with the "magnification" of space expressed during Cubism, which added an aesthetic fourth dimension: "[It] is the moment of limitless escape evoked by an exceptionally just consonance of the plastic means employed". As Le Corbusier stated, the phenomenon of the ineffable space became a means and a goal of the spatial concept of Sainte Marie de la Tourette:

"Lorsqu'une œuvre a son maximum d'intensité, de proportion, de qualité d'exécution, de perfection, il se produit un phénomène d'espace indicible: les lieux se mettent à rayonner, physiquement ils rayonnent. Ils déterminent ce que j'appelle "l'espace indicible", c'est-à-dire un choc qui ne dépend pas des dimensions mais de la qualité de perfection. C'est du domaine de l'ineffable." [6].

\section{A monastery à l'état pur}

In March 1953 Révérend Père Marie-Allain Couturier commissioned Le Corbusier to build a Dominican monastery in Eveux-sur-l'Arbresle not far from the city of Lyon in France [7]. As the editor of L'Art sacré and supporter of the arts, Couturier saw the commission of Le Corbusier as a vessel to which the Dominican monks could live surrounded by and within the culture of their times. Though strikingly contemporary in its form and material choices, the building was deeply rooted in the traditions of Cistercian and Dominican monasteries, namely Le Thoronet, a Cistercian monastery in the South of France. This 
informed the design, and served at the request of Couturier as the prototype to La Tourette, both in its social and spatial organization.

Based on the traditional plan of a rectangular cloister, Le Corbusier developed a contemporary interpretation of the medieval monastery: A monastery à l'état pur with amenities for comfort reduced to the bare minimum allowing the friars to live their lives according to the rules of $13^{\text {th }}$ century practice [8]. The monastery, which houses the functions of daily life, is grouped as a large Ushaped form around an inner courtyard, which, though not directly accessible, serves as the primordial cloister garden. Instead of the traditional cloister circulating along the periphery of the garden, a hallway in the form of a cross connects all essential functions of the monastery including the freestanding church that encloses the ensemble to the North.

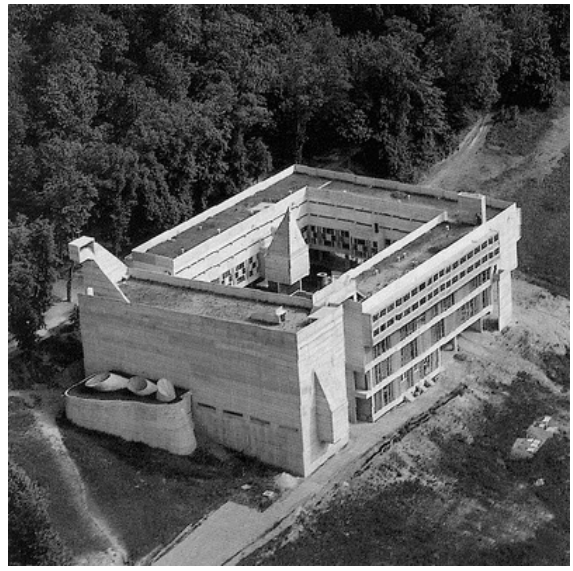

Figure 1: Monastery Sainte Marie de la Tourette, Le Corbusier, Arbresle, 1957.

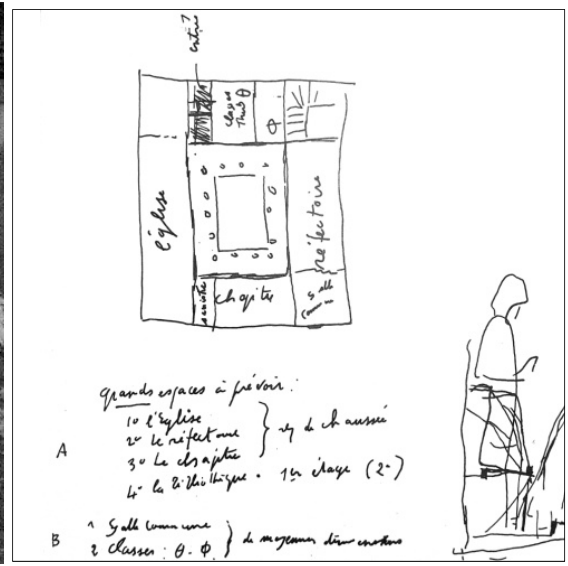

Figure 2:

Sketch by Père

Couturier in letter to Le Corbusier, dated Aug. 4, 1953.

The spatial organization strictly divides the building into three functions of daily life: vie commune, vie intellectuelle and vie individuelle, reflecting degrees of social interactions within the community of friars. All spaces serving communal functions (vie commune), such as refectory, church and chapter, are located on the lower level connected by the cross-shaped "cloister". The level above is dedicated to the intellectual functions (vie intellectuele) and houses the entry area with its parloirs, the library, several class and communal rooms for disciples and friars, as well as a small oratory for private prayers. The oratory is conceived as a freestanding sculptural object occupying the cloister garden, and as such can be seen as a reminiscence of the lavabo of Le Thoronet. Though different from Le Thoronet where the monks lived in dormitories, the last two floors contain all the individual functions (vie individuelle): one-hundred individual cells for the friars and disciples, in addition to communal bathrooms and cells to care for the sick. Obliged by the rules of their religious order, the 
friars spend most of their day alone in their individual cells, engaged in study and prayer away from the community. While all communal circulation areas are oriented to the courtyard, all individual cells open up to the surrounding nature and are connected through a loggia with the open environment serving as a threshold between inside and outside.

The functional separation of individual and communal life can be traced back to the spatial composition of the Chartreuse Saint-Laurent de Galluzo in the Valley of Ema, which Le Corbusier experienced and internalized during his voyage to the Orient in 1911 (and 1907) [9]. The spatial and social organization of the charterhouse in Ema served as an archetype for many of Le Corbusier's buildings and turned into a Leitmotif for the development of the logis of the machine age. We find it in variations in the cellules-d'étudiants of the Swiss Pavilion and Maison du Brésil in the Cité Universitaire in Paris, in the arrangement of the apartments and service facilities for the Unités d'Habitations in Marseille, Rézé-les-Nantes, Briey-en-Forêt, Berlin and Firminy as well as here in La Tourette.

"Pour nous, la pauvreté des bâtiments doit être très stricte et par conséquent cela implique que les nécessitées vitales communes soient respectées: le silence, la température suffisante pour le travail intellectuel continu, les parcours des allés et venues réduits au minimum." [10]. As a moral commitment to the Dominican order, keeping materials and spaces to the essential minimum was of utmost importance to Couturier. In the scantiness and honesty of the exposed concrete as the major construction material we see Couturiers vision come to life. Le Corbusier reduced the palette of materials to concrete, crude machine applied plaster, wood and natural stone, leaving all materials in their unfinished, raw form - cold, uncomfortable, honest - like a permanent memory of the woolen, white-and black cowl of the Dominicans scratching the skin. As such, I would like to ague that colour, which is used only sparingly and as colour accents throughout the building and in combination with subtle natural lighting, not only has a spatial, but also a spiritual dimension in humanizing this place.

\section{Development of the colour schemes}

Within all of the monastery's projects, design and artistic expression is wholly attributed to Le Corbusier, whereas construction documentation and planning were left, for the most part, to his office staff and long-term collaborators. During the planning and construction phase he was occupied with several largescale projects, and between multiple trips to India and America, research shows that he did not find much time to continue his involvement past the design stage. He entrusted the further development to his employees, Fernand Gardien, who served as the construction manager and representative of the Atelier Le Corbusier, and Iannis Xenakis, a young architect and composer from Greece [11].

The paintwork was executed by the local firm, A. Thibert, Peintures, Vitreries, Platreries, Drogueries located in Abresles. Facing severe financial problems and delays in the construction process, the paintwork for the monastery 
started at the beginning of January 1959 [12]. At the beginning of April of the same year, three months before the friars move into their new domicile, most of the paintwork seemed to be finished [13]. The construction of the church was delayed and only finished after the friars moved in. Debates about the acoustics of the church delayed the process even further [14], and Le Corbusier considered shortly diamantes acoustiques for the south wall as a sound diffusing system (Fig. 3) [15]. Only after he abandoned the idea of coloured diamantes acoustiques - which would have given the space a different weight - was he able to enterprise the chosen colour design that centered the space on the sanctuary.

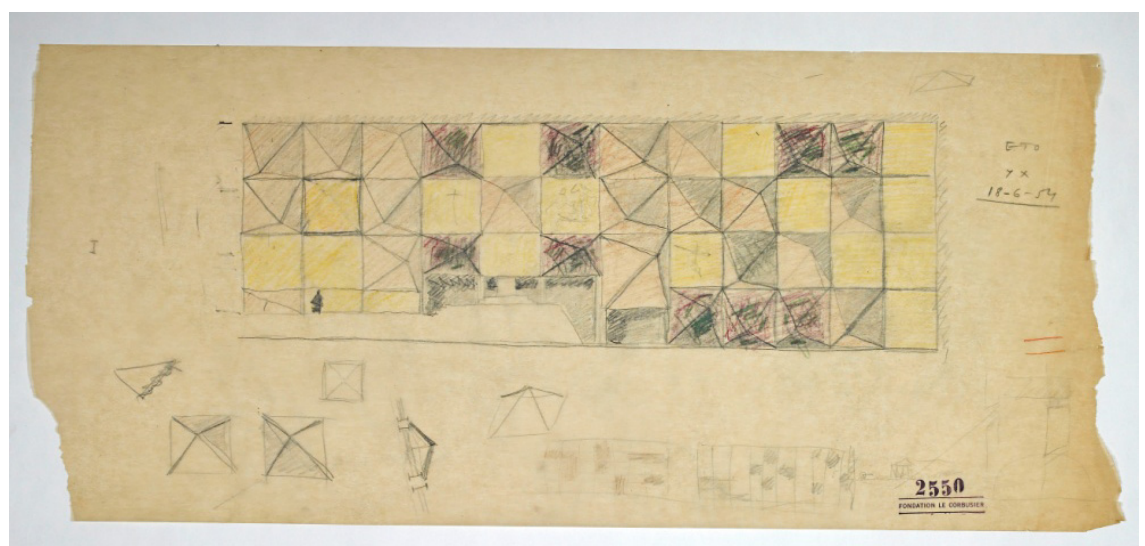

Figure 3: $\quad$ FLC 02550, Diamantes acoustiques, Xenakis, dated June 18, 1954.

The invitation to bid for the paintwork, dated March 15, 1956 [16], reveals that Le Corbusier originally envisioned, both a monastery and a church, in blanc absolu, contrary to what was executed three years later. In addition, ten percent of the total surface was planned "in patches of bold colours designated by the architect and specified by colour samples provided by the same" [17]. As an obvious memory of the whitewashed monasteries that he saw during his Voyage to the Orient in 1911, this structure would have been the only post-war building painted white in its totality. (During their "Voyage to the Orient" in 1911 Le Corbusier and his friend August Klipstein visited more than 15 monasteries including Mount Athos in Greece.) It could have been considered a reminiscence of the symbolic meaning of the whitewash of the Law of Ripolin in which Le Corbusier claimed in 1925: "The white of the whitewash is absolute, everything stands out from it and is recorded absolutely, black on white; it is honest and dependable." Due primarily to financial problems of the friary, he abandoned this thought later in the design process and decided instead to limit whitewash only to plastered surfaces of the interior and exterior walls. Pure white was replaced by exposed, grey concrete, which greatly emphasized the ascetic character of the church and the monastery. (This gradual change to a more ascetic interior space also becomes evident in abandoning the original plan to build a sound diffusing system on the south facing wall of the interior of the church. Though aware of the sound problem in the all-concrete church, Le 
Corbusier and Xenakis decided against the diamantes acoustics, which they had designed in 1959. This decision was based primarily on financial difficulties, but also to avoid a tumulte visuel that would have compromised the clarity of the form. The original drawing (FLC 2550, dated June 18, 1959) shows that the diamantes acoustics were to be painted in yellow, ochre, red and green.)

The few still-existing sketches and notes of Le Corbusier attest to the creative process involved in developing the colour scheme for La Tourette. Different from the Unité d'Habitation in Marseille and other buildings, where we find multiple entries in his carnets and evident documentation about the development of the colour schemes, the colour gestalt of the church of La Tourette, though remarkable, seems to have been designed at a spur of a moment during one of Le Corbusier's last visits to La Tourette. (Footnote in L'Art Sacré, March-April 1960, Le Corbusier, Un couvent dominicain, p. 14: "Au cours de sa dernière visite, Le Corbusier a définitivement arrêté son parti. Les murs de l'église resteront gris béton, mais le sanctuaire sera auréolé de couleur: le mur de séparation de la sacristie sera rouge, celui de la chapelle du Saint-Sacrement jaune et noir avec le plafond bleu. Les canons de lumières seront l'un noir, l'autre rouge et le dernier blanc. Au fond, le confessionnal sera rouge.") A note, written on the day of his return from La Tourette, reveals the importance attached to the correct execution of the colour design:

"Note à l'attention de Gardien

Il faudra me donner dès votre rentrée de La Tourette:

a) les décisions sur les couleurs

b) les décisions sur la lumière

C'est très important que je puisse revoir cela avec vous. Le Corbusier

Voyage à La Tourette de L-C + Gardien 28 et 29 Mars, 1960 [18]"

Handwritten notes on the plan of the church [19], likely written on a day visiting La Tourette at the end of March 1960, show the final design of the colour scheme (Fig. 4): All walls in grey, exposed concrete, the floor surrounding the altar in black slate, the central altar in white stone, the wall of the sacristy in red, walls between crypt and main nave yellow, and on the side facing the crypt in yellow, black and red; the three openings of the canons de lumiere in black, red and white. Although not executed, the plan still shows dividers made of monolithic, black lava stone between the altars to screen the view. Together with the red wall of the confessional on the east wall and the coloured light entering through the horizontal windows in the choir area, Le Corbusier created a sublime colour space that circulates the sanctuary as a coloured aureole enveloping the holy place of liturgical consecration.

\section{The cells}

Each cell is configured as a microcosm of a hermitage, designed for the individual to consecrate to study and prayer away from the community. Despite the minimal spatial volume $\left(13,37 \mathrm{~m}^{2}\right.$ for friar cells, $10,83 \mathrm{~m}^{2}$ for disciple cells $)$ the room is designed to provide for all essential daily functions: washing/sleeping/studying. The dimensions of the room, $5,92 \mathrm{~m} \times 2,26 \mathrm{~m} \times 2,26 \mathrm{~m}$ 


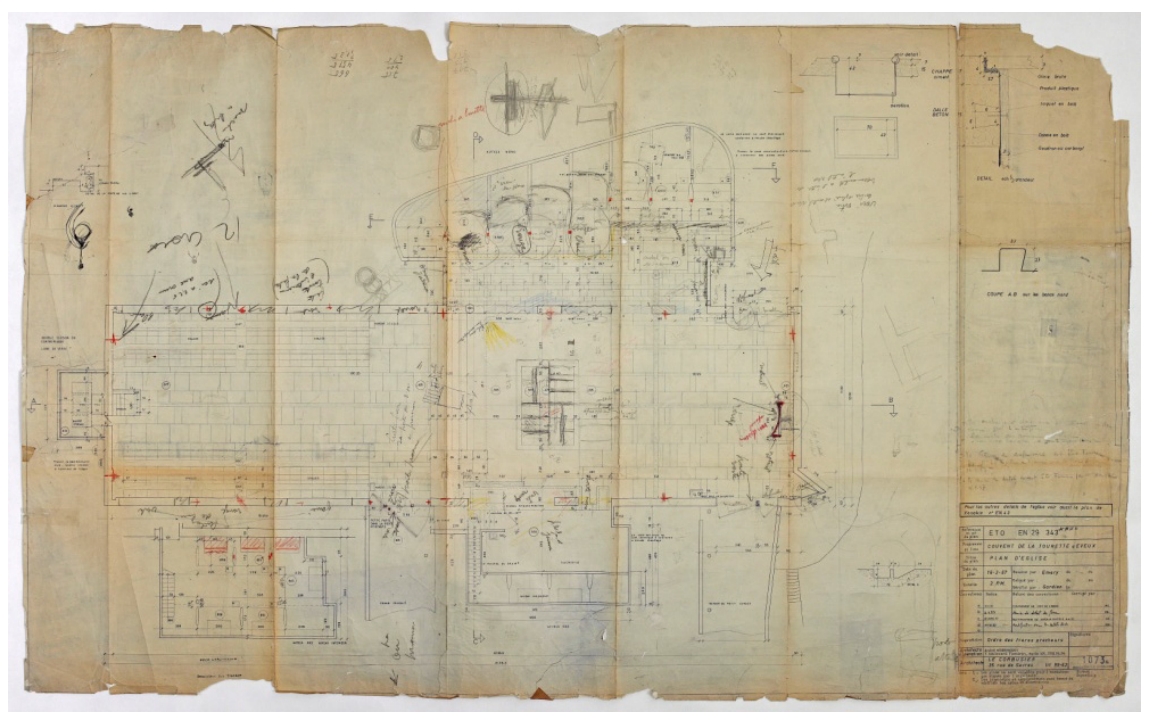

Figure 4: FLC 1073 A, Plan of church with handwritten notes indicating colours, Le Corbusier, La Tourette, 1957.

(friar cell) which are based on the Modulor, create a linear space with an unusual low and elongated proportion, reminding us of the children's bedrooms of the Unité d'Habitation in Marseille, which clearly served as a precursor to the cells in La Tourette. (The Modulor is an anthropometric scale of proportions developed by Le Corbusier in the tradition of Vitruvius, Leonardo da Vinci and others using the proportions of the human body to create a harmonic appearance of architecture. The Modulor was first published in 1950, followed by Modulor 2 in 1955.) The cell's grotto-like character is emphasized by a rough-textured, machine-applied plaster (ciment au canon) painted in blanc absolu creating a sense of pureness. Across from the study desk, the texture changes to fair faced plaster $(1,83 \mathrm{~m} \times 2,26 \mathrm{~m})$. This creates a subtle subspace through which the reflection of larger amounts of light on the smooth surface gradually diminishes towards the back of the cell.

The colour scheme for the cells is identical for all one hundred cells in the monastery, emphasizing the character of the cell as a space of silence and solitude. The floor is covered with dark green linoleum optically connecting the interior with the green of the surrounding vegetation. The frame of the window element, designed as a meander, is painted in a vivid yellow (jaune vif). This allows the ceiling to continue into the exterior space without interruption, and connects the study desk and loggia, though divided by a glass membrane, to a singular space for contemplation. All movable elements, such as the aerateur left of the study desk, as well as the door to the loggia are painted vivid green (vert vif). (The aerateur is painted green on the inside, whereas the outside is left in natural wood (gaboon).) Radiator and heating pipes are painted black and disappear optically against the dark wall; drains are painted in cobalt blue. On the other side of the cell, the wooden, ceiling-high entrance door is painted in 
bold yellow and separates the individual space from the communal hallway. Next to the door, another movable aerateur, painted in vivid red, provides ample ventilation during hot summer days. On the side of the hallway, yellow doorframes together with red aerateurs create a coloured rhythm, captivating, in tandem, a visual motion provided by the clerestory windows shortening the long hallways painted in white.

"Each house has its own courtyard, and the intimacy in them is as perfect as in the garden of the Carthusian Monastery of Ema where, as you may recall, we had a fit of spleen. Beauty, joy, serenity gather here, and a wide, semicircular portal, closed by a door lacquered in either red or green that opens onto a spacious exterior! The trellis assembled latticework casts a green shadow, its white arcades bring comfort." [20], wrote Le Corbusier during his Voyage to the Orient. The memory of his visit echoes in the polychromy of the cells: here the red and green doors open onto a spacious exterior, and the green doors of the loggias open the view into the canopy of trees.

Initially, Le Corbusier thought to differentiate the cells through colour much in the same way as executed in the student rooms of the Swiss Pavilion at the Cité Universitaire in Paris. A sketch dated July 19, 1957 shows the design of the cell with colour notations; notably, the ceilings were supposed to be painted in red alternating with green ceilings [21]. According to the sketch, cells with red ceilings were to be combined with green bedspreads (with grey, black and white patterns, or, alternatively with stripes), whereas cells with green ceilings were to be combined with yellow bedspreads (Fig.5). Another drawing shows a possible differentiation of the cells according to the status of the inhabitant [22]. While it is not clear, what exactly should have been painted (ceiling, doors?), the plan reveals forty-six green, twenty-two yellow, twenty white, and some red and purple cells, which, with exception of a few, correspond with the distribution of cells for disciples, friars, the sick and others. A third drawing, contained in the building archive of La Tourette, reveals the idea of differentiating the doors to the loggias through colour, as well [23].

The final decision about the colour scheme for the cells was made on April 23,1958 , as the sketches and drawings signed by Le Corbusier reveal [24]. Hues indicated in the drawings are taken from the colour palette "Palette 'Le Corbusier"'. (The Nomenclature of hues for the cells had been taken from the "Palette Le Corbusier, Peintures Berger": jaune vif, Nr. 2; rouge, Nr. 4; vert vif, Nr. 14; bleu foncé, Nr. 12; noir and blanc.) He developed this standardized colour palette in collaboration with Peintures Berger, which by 1959 contained about 40 different hues using the paint products Matroil and Matone [25]. While he insisted for most of his post-war buildings to use the industrially produced paints by Berger, it is not clear whether he indeed employed the paints in $\mathrm{La}$ Tourette. The documentation left at the Fondation Le Corbusier reveals that he employed, for the church, a new product produced by Cellapol (Cellapol Peinture Vinylique). Arising difficulties around the paint product Matroil during this time, in conjunction with the construction of the Pavillon Brésil, may have led to this decision [26]. 


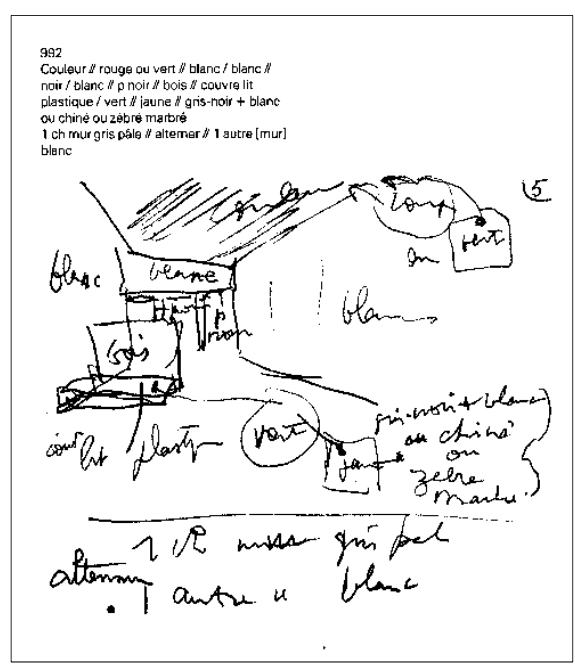

Figure 5: $\quad$ Sketch 992, Le Corbusier's Carnets, Vol 4, 1957-1964, cell in La Touette.

Different from his purist polychromie architecturale, which focused primarily on spatial articulation and modification based on the spatial properties of colour, we see, as in many of his post-war buildings, the idea of a superimposition of coloured rhythms (ceilings, doors, curtains, bed spreads) with repeated modules (cells) and other architectural elements in order to create variety in a system of standardized elements. This change is first observed in the 1933 colour scheme for the student bedrooms in the Swiss Pavilion [27]. With the construction of the Unite d'Habitation for Marseille in 1945, this theme is further explored, and Le Corbusier developed a sophisticated system of superimposed colour rhythms of loggias, rue intérieures and apartments juxtaposed with a system of proportions and dimensions dictated by the Modulor. In the case of the cells of La Tourette, colour not only had a spatial dimension in the symphony of architectural elements, but social dimension in individualizing the cells of the friars.

The differentiation through the colour of the cells was seen by the Dominican friars as a personal distinction of the individual from the community, and contrary to the conditions described by Couturier in his letter to Le Corbusier on August 4, 1953: "Souvenez-vous que notre type de vie nous est absolument commun à tous et par conséquent n'appelle aucune différenciation personnelle à l'intérieure des groupes." [28]. As a result, the idea was abandoned after a discussion with the friar community, and instead, a uniform colour design for all cells was adopted.

\section{The church}

As a built expression of existential minimalism, the church surprises with its plainness and pureness, invoking a sensation of transcendental solemnity. This sensation is first achieved through the creation of a large door at the end of the 
conduit that leads to the church, and opens the view into a dark room illuminated only by a few windows and openings. A simple Cartesian room, bare of any decoration and built out of pure concrete, welcomes the visitor and opens the view to a built, polychrome still-life made of boldly painted walls and dazzling light framed in concrete. Comparable to the white entry hall at La Roche House in Auteuil, built in 1924, the main nave of the church is conceived as a "negative space". The built emptiness turns into a perceptible medium: A space of pure abstraction striped of any decoration, and as such a built expression of the symbolic cleansing of the Law of Ripolin. Colourful window slits in the bold colours of red, green and yellow barely illuminate the choir area, and the dark nave visually disappears into the black hole of the organ attached to the West wall. This creates a space placed between the constant tension of medieval mysticism and modern architecture, exhibiting light and darkness, natural materials and expressive colours, and evoking with its visual acoustics the architectural tension desired by Le Corbusier.

Boldly painted surfaces (crypt, sacristy and confessional) and coloured light surround the main altar as an aureole emphasising the altar as the focal point of the composition: "C'est avec les autels que le centre de gravité sera marqué ainsi que la valeur, la hiérarchie des choses. I y a en musique une clé, un diapason, un accord. C'est l'autel, lieu sacré par excellence, qui donne cette note-là, qui doit déclencher le rayonnement de l'œuvre." [29]. The main nave is conceived as a spatial unit, mainly through its Cartesian form and material choices, but also emphasizes, through the unifying darkness and achromatic materials of the main space, a built "inversion of the traditional church" [30]. The main nave pushes over the colour space of the sacristy and the crypt; both are linked underneath the nave, but without direct access from it. The contrast of the colourless main nave (with the exception of a few colour splashes), built from materials left in its natural state, such as the black slate, grey concrete and white stone for the altars, with the colourful spaces of the transept (sacristy and crypt) creates a space of poetic lyricism built upon the spatial and emotional powers of colour. As Le Corbusier wrote, in reference to the spatial dynamics and physiological effects of colour in architecture, the space demonstrates "la couleur c'est de la dynamite" [31] (Fig. 6).

Where the dark nave can be seen as a built analogy of monastic life, the exploding colour space of the transept, contrastingly, can be interpreted as a modern version of the medieval representations of the "New Jerusalem". The chosen colour scheme of yellow, red, blue and black surfaces the crypt and draws to the colour schemes of gothic cathedrals, creating a mystical space of pronounced sculptural effect: "As a representation of the 'New Jerusalem' the gothic cathedral was built without windows, but rather with luminous wall infills, walls like glowing crystals and gems, from which the colour schemes of the cathedral are derived: gold-yellow, ruby-red, ultramarine, and emeraldgreen." [32]. Bathing the crypt into diffuse and timeless light, the gothic window is transferred into a still-life of glowing walls, emitting radiant energy as both reflected light and visual dynamism (Fig.7): 


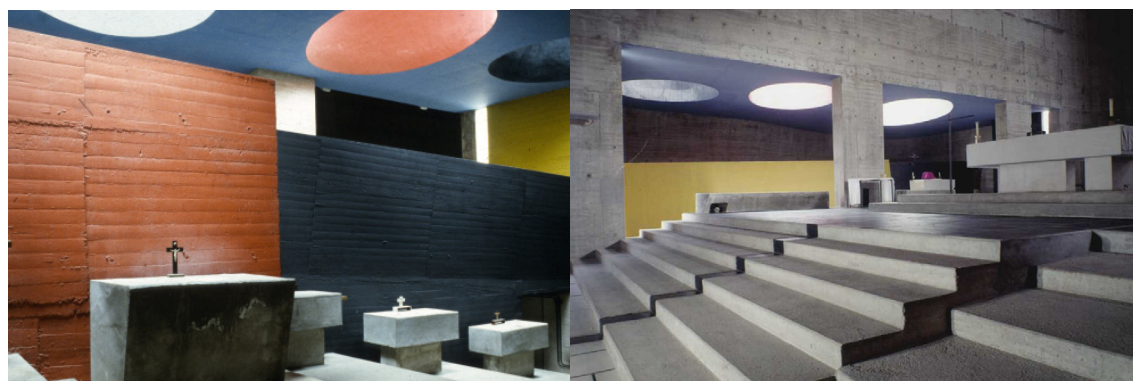

Figure 6: Polychromie architecturale, Figure 7: Modern chiaroscuro: in crypt (Chapel Saint- Crypt seen from main Sacrement). nave.

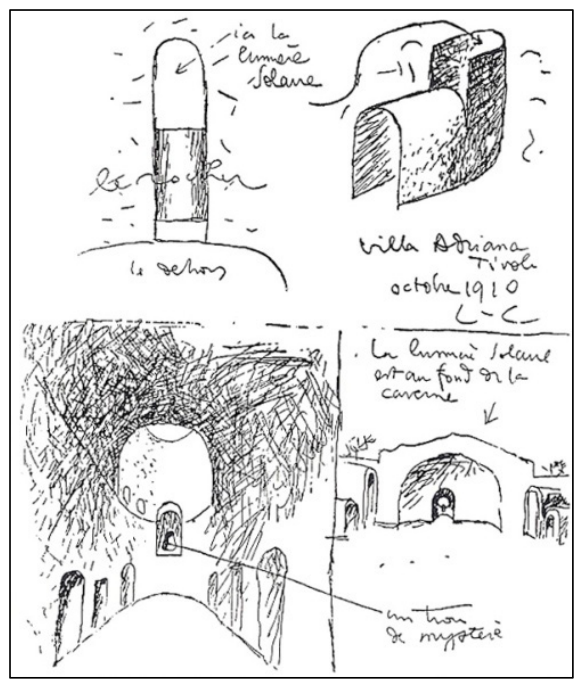

Figure 8: $\quad$ Sketch Le Corbusier, Tivoli, Villa Hadriana, 1910.

"Et alors le problème d'éclairage est toujours celui-ci, c'est de savoir ce qu'est l'éclairage : ce sont des murs qui reçoivent une lumière. Ce sont des murs éclairés. L'émotion vient de ce que les yeux voient, c'est-à-dire les volumes, de ce que le corps reçoit par l'impression ou pression des murs sur soi-même et ensuite de ce que l'éclairage vous donne soit en intensité, soit en douceur selon les endroits ou ils se produit. (Le Corbusier 1960: 11-12)" [33].

Together with Iannis Xenakis, Le Corbusier developed two different types of canons de lumière that not only control direction and reflection angle, but also determine the exact quantity and quality of the light received and reflected from the painted walls. The first is a transformation of the light tower, as depicted in a sketch made during his visit at the Villa Hadriana in 1910 (Fig. 8). Though developed as an idea for the Basilica in Sainte Baume, in order to create a "symphony of light, shadow and semi-shade of extraordinary effect" [34], they 
are built for the first time in La Tourette. Capturing the light from the North, these conical canons de lumière create a mystical constant and diffuse light of extraordinary effect that recall the divine light of the New Jerusalem. The cones, painted in red, white, and black, turn into mystical, bodiless openings, a reminiscence of the true de mystère in the Villa Hadriana. The second type of canons de lumière are placed above the sacristy: seven prismatic light sources positioned to capture the light from the South. In contrast to the crypt, the light here is sharp, almost aggressive, reflecting from the red wall of the sacristy onto the dark room of the nave. The choice of red for the wall and yellow for the ceiling emphasises a warm glow created through the reflection of light from the painted surfaces. He uses a similar effect, though less pronounced, in the choir area. White sunlight reflected on painted surfaces, in primary colours, enters as a red, yellow and green glow in the darkness of the space.

In working with stark light/dark and colour/no colour contrasts, Le Corbusier creates a modern chiaroscuro as an art abstrait (Fig.7), breaking the boundaries between sculpture, painting and architecture as demanded in his synthesis of the arts. He masterfully uses the interdependence of colour and light to create an art abstrait of poetic lyricism and spiritual asceticism within La Tourette. Light, colour, proportions and dimensions are perfectly arranged creating through their visual acoustics the phenomenon of remarkable, ineffable space.

\section{References}

[1] Eliel, C. (ed.), L'Esprit Nouveau: Published in Paris, 1918-1925; with essays by Françoise Ducros, with an English translation of The Law of Ripolin (La loi du lait de chaux) by Ozenfant A. and Ch.-E. Jeanneret, first published in L'Art décoratif d'aujourd'hui, Crès: Paris, 1925.

[2] FLC J1 (7), 340-342, letter written by Le Corbusier to Jakob Ott, dated July $1,1957$.

[3] Ozenfant, A. and Jeanneret, Ch.-E., Après le Cubisme. Editions des Commentaires: Paris, 1918. "L'idée de forme précède celle de couleur. La couleur dépend entièrement de la forme matérielle."

[4] Le Corbusier, Espace indicible, L'architecture d'aujourd'hui. Special issue: Art, January 1946, unpaginated. Republished in Modulor 2 (1955). Published in English in Le Corbusier, New World of Space. All quotations in this paragraph are from Joan Ockman with Edward Eigen, ed., Architecture Culture 1943-1968: A Documentary Anthology, Columbia Books of Architecture/Rizzoli: New York, p. 66, 1993.

[5] Pearson, C., Le Corbusier and the Acoustical Trope: An Investigation of Its Origins, Journal of the Society of Architectural Historians 56 (2), pp. 168183, 1997.

[6] Le Corbusier, Un couvent dominicain, L’Art Sacré (3-4), pp. 16-17, 1960. Recorded meeting of Le Corbusier with the Dominican Brothers, not dated.

[7] Petit, J., Un couvent de Le Corbusier, Les cahiers des forces vives: Paris, p. 8, 1961 . 
[8] Boesiger, W. (ed.), Le Corbusier, Euvre Complète, Vol.7, 1957-65, Birkhäuser: Zurich, 1965, $6^{\text {th }}$ edition, p. 33: sketch of Dominican monastery.

[9] Le Corbusier, Voyage d'Orient carnets, Electa, Fondation Le Corbusier: Paris, Milano, 1987, 1994, 2000.

[10] Petit, J., Un couvent de Le Corbusier, Les cahiers des forces vives: Paris, pp. 25-26, 1961. Letter written by M.-A. Couturier to Le Corbusier, dated August 4, 1953.

[11] Xenakis, I., The Monastery of La Tourette, The Le Corbusier Archive, La Tourette and Other Building projekts 1955-1957, ed. Allen Brooks, Garland Architectural Archives: New York, London, Paris, pp. xi-xiii, 1984. In retrospect, Iannis Xenakis should be acknowledged as the author of many of the details designed for La Tourette including the pans de verre and the pans ondulatoires.

[12] FLC K3 (13) 406, dated January 7, 1959

[13] FLC K3 (13) 409, dated April 10, 1959

[14] Note in carnet, dated March 29, 1960: "attention L-C étudier acoustique église La Tourette".

[15] FLC 2550, dated June 18, 1959, drafted by Xenakis?

[16] FLC K3 (20) 462, dated March 15, 1956, invitation to bid for paintwork. “5./ prévoir le rendu de la totalité du Couvent et de l'église en blanc absolu sauf $10 \%$ de la surface totale sera traitée par des taches de couleurs vives désignées par l'architecte avec échantillons de couleurs fournis par celuici”.

[17] FLC K3 (20) 462

[18] FLC K3-11 343, dated March 30, 1960

[19] FLC 1073 A

[20] Žaknić, I. (ed.), Le Corbusier, Journey to the East, MIT Press: Cambridge, p. 23, 1987

[21] Franclieu, F. (ed.), Le Corbusier, Carnets, Vol. 4, 1957 -1964, Electa: Milano, Paris, New York: 1982, Sketch Nr. 992, dated July 19, 1957.

[22] FLC 1332, not dated

[23] E. To 188, Archive La Tourette, Plan of the monastery with cells, dated July 26, 1956, with color specifications. Color specifications may have been added later. The community of friars disapproved this color scheme.

[24] FLC K3 (18) 240, Microfilm, sketch, plan of cell mit color specifications, dated April 23, 1958 and FLC K3 (18) 239, sketch showing loggia and entrance to cell, dated April 23, 1958.

[25] Klinkhammer, B., La Polychromie - Peinture, sculpture et architecture, Euvre Plastique, Rencontres de la Fondation Le Corbusier, ed. Prelorenzo, Claude, FLC and Editions de la Villettee: Paris, pp. 144-163, 2005.

[26] FLC K1-1 308, Note à l'attention de Gardien: " Concernant les lettres du 24 novembre 1960 à l'Entreprise Jean Martin et au Directeur de la Maison du Brésil, il faut se méfier du matroil pour la peinture extérieure. C'est impossible.” Dated and signed Le Corbusier, November 30, 1960. 
[27] Klinkhammer, B., Towards Standardization and Industrialization: Le Corbusier's Swiss Pavilion and his Polychromie Architecturale, Proc. of the 92nd ACSA Annual Meeting, American Collegiate Schools of Architecture: Washington, pp. 382-388, 2004.

[28] Letter written by M.-A. Couturier to Le Corbusier, dated August 4, 1953, published in Petit, J., Un Couvent de Le Corbusier, Les cahiers des forces vives, Nr. 15: Paris, pp. 25-26, 1961.

[29] Le Corbusier, Un couvent dominicain, L'Art Sacré (3-4), pp. 16-17, 1960. Recorded meeting of Le Corbusier with the Dominican Brothers, not dated.

[30] Kessler, T., Einige Bemerkungen zu Phänomenen des Raumes im Kloster Ste. Marie de la Tourette in Eveux, Synthèse des Arts. Aspekte des Spätwerks. Ausstellungskatalog des Badischen Kunstvereins Karlsruhe, 23. März bis 18. Mai 1986. Ernst: Berlin, 1986.

[31] Le Corbusier, Les tendances de l'architecture rationaliste en rapport avec la collaboration de la peinture et de la sculpture, Rapporti dell'architettura con le arti figurative. Rome: October 25-31, 1936.

[32] Kessler, T., p. 172, translation from German to English: author

[33] Le Corbusier, Un couvent dominicain, pp. 11-12.

[34] Boesiger, W. (ed.), Le Corbusier, Euvre Complète, Vol.7, 1957-65, pp. 28 